\title{
LAND, HISTORY AND IMAGINATION, OR REMARKS ON THE FOUNDATIONS OF THE NEW PATRIOTISM
}

Wiktor WERNER

\section{ABSTRACT}

Article will address the issue of changes in national identity in Poland in the 20th and 21st centuries. Issue will be considered with the importance of territory in the sense of man's national identity - this will apply to territories which became a part of the Polish state after World War II: in particular, the lower Silesia. The main problem will be, therefore, the presence in the common consciousness concepts describing nationality in relation to the category of territory. Area of empirical research will be artefacts of mass culture - and specifically Polish popular literature resulting in the mentioned time.

\section{KEYWORDS:}


The article will address the issue of changes in national identity in Poland in the 20 th and 21 st centuries. The studied issue will be the sense of patriotism as well as the presence of the image of the territory in the historical consciousness and in the sense of one's national identity. It will concern both the territories which have known multiculturality and those which became parts of the Polish state after World War II: in particular, Lower Silesia. The issue under study will be, therefore, the presence in the common consciousness of the concepts describing nationality in terms of relation to land, area, territory. Mass culture artefacts will be the area of empirical research: namely Polish popular literature created in the mentioned time.

The evolution of social consciousness and world-view will be described, in which concrete terms take the form of symbolic terms. The described process is evolution understood as a "rhizome", i.e., it is multi-linear and inconsistent. Evolution does not involve just the state of mind of "patriotism" but also the components of consciousness related to it which make it possible.

Patriotism has been and sometimes is a concrete term in the sense that it was based on realistic grounds. These grounds were concrete phenomena and the emotional response to them in the human psyche.

Such real phenomena included family ties, to which the emotional response was the traditional "respect" or "fear" of the father, then transferred onto a ruler, who frequently used styles reflecting the authority of a "sire". Concrete phenomena should also include direct social interactions, neighbourly or economic (established via direct exchange in a more external environment than neighbours), as well as the relations of participation in specific activities (religious rituals, military service).

First and foremost, the inhabited and "domesticated" space was a real value. For this reason, fatherland was treated as a particular extension of home: a sphere of "familiarity", inhabiting which defines us as the state of being "from here". The sense of identity formed by the knowledge of the Land, fields, meadows, woods, lakes and rivers, and all the nature filling the geographical space. Such a sense also stemmed from the awareness how much work, toil, and sweat it cost to build houses and towns, plough fields, clear fallow land, plant trees, dig wells... It was the awareness of the bond forged, generation after generation, with hard work and often in battle for the Land and the right to live in it. It was in a concrete space and concrete Land that people loved, bore children, started families, forged neighbourly ties, friendships and collaboration relationships, all kinds of relations between humans, which were known to be "ours" and "familiar". 
The specific nature of the phenomena on which the "intuitive patriotism" was based affected the nature of this form of collective identity. For Jews, it was their bond with religion and the Torah, the holy book containing a religious and historical description of the community's past and a vision of its future, as well as categories allowing them to understand the present in relation to tradition and the possible expectations of the future. Sedentary societies tended to spontaneously identify with the "Land of Fathers" as the space of social "rooting" and the area inhabited by people to whom the individual could allegiance: e.g., an economic community, community of fate (subjects to one lord), faith, communication community (sphere of linguistic influence), look ("racial"traits), lifestyle (clothes, customs).

In modern times (in Europe this process took place between the 16th and 19th centuries) the collective consciousness was significantly transformed. The dynamic political changes in almost whole Europe at that time, combined with the stratification of societies, emergence of the middle class and intelligentsia, made more and more people ponder the questions of legitimacy of power and its actions in a given territory. The Hussite movement which questioned the authority of the emperor, peasant revolts in German states against the rule of local princes, the resistance of Zaporozhian Cossacks against Polish and Russian nobles are all examples of concrete historical events attesting to the growing need of an authority which woutl be "ours", or towards which a given collective would feel close and not foreign. Among other reasons, the Partitions of Poland were possible because from the 16th to the 18th centuries the idea of a "nation of nobles" was promoted in the Both Nations Commonwealth, making peasants second-class citizens virtually deprived of national classification. Therefore, a peasant was mentally tied to the land he farmed and where he lived, he felt affiliation with a religion (albeit identified in fairly territorial terms of one's priest, church, parish), treating his lord (pol. pan) and master as belonging to a different, foreign nation. The Polish szlachta (nobility) paid a steep price for its alienation from the lower strata: having lost its state and guaranteed privileged position in the 18th century, it suffered spectacular disasters in the 19th trying to convince the people to fight for independence. It was impossible, however, without world descriptions which would explain to the people its affiliation to the nation understood as a historical and ethnic community blending all social strata and groups. Such knowledge began emerging in the second half of the 19th century, from intelligentsia, the social group able to produce such knowledge, who wanted to spread it far and wide. It was a whole discourse of stories (both written and oral, addressed to the people: sermons, talks, simple literature, journalim, lectures given along various practical courses held for village dwellers. To succeed in persuasion, these stories had to refer to the knowl- 
edge about the world which had already been accepted and internalised in collective identity. Which, at that point in time, were the sense of connection with the land/ territory and the awareness of religious affiliation.

The rhetorical mechanism which led broad social masses to identify with the idea of Polishness was the shifting of acceptance from that which had already been recognised as their own to the values and ideas described as the outcome/conclusion of what had been accepted. The idea of the Polish nation was described in ethnic terms as a linguistic community, in historical as a collective bound by a common historical experience, common roots and common heritage; religious, since it has been Christian (Catholic, in particular) for ages; existential, as it prefer a rustic, country way of life; territorial inhabiting certain lands for centuries. The latter category was very important in the 19th-century national discourse, for it referred to the actual phenomenon of living in a specific place and emotional response. The Polish state was restored in 1918, yet not in its borders from 1776, which led to the sense of loss and longing for "Great Poland". This issue was particularly intense after 1945.

In the mid-20th century, the political ones (both territorial, legal, and systemic), social, and ideological circumstances under which the Polish society lived changed drastically. The Polish territory changed under the agreements between the Big Three reached in Yalta and Potsdam cutting off from Poland the lands which traditionally took part in constructing the idea of Polishness and Polish state in the 19th century.

The 19th-century egalitarian concept of the Polish nation - comprised of all social groups - still used some elements of the elitist "nation of nobles" concept, predominant until the end of the 18th century. Motifs which made a successful transition are the "militaristic" theme of the Polish nation as a defender of civilisation and faith against Eastern invasion (bulwark) and the existential theme of connection to the land (both noble, aristocratic and peasant, agrarian). These motifs made the sense of national identification and patriotism more concrete by tying it to space - broadly understood Eastern Borderlands (Pol. Kresy) as well as particular territories, the Vilnius Region, Volhynia, Podole, so beautifully described in Polish literature. The motif of bravery and sacrifice of many generations who defended these lands from the Tatars, Turks, Muscovites, and other foes, and who worked hard to manage them built the social sense that the present was connected to the past and the connection between all social (and, to a lesser extent, religious and linguistic) groups coming from "here".

These lands were taken from the Polish state in 1945, and due the political situation of the People's Republic of Poland (PRL) this fact could not be presented officially as a loss or result of violence but rather as a kind of "historical justice". The alteration of political system and exchange of ruling elites not only enforced the recognition of 
the new borders in terms of international law but also the acceptance of the "justice" of this change: that is, reformulation of knowledge and historical consciousness so that the change would not be seen as robbing the Polish nation but placing it in the right space instead. It was significantly easier, in common perception, to gain the acceptance to the incorporation into Poland of the lands which were torn from the orbit of Poland in the middle ages and in 16th-17th centuries (in terms of both political, cultural, and linguistic influence) and gradually lost its Polish/Slavic identity for a German one than to the loss of the lands which had left a very strong mark both in the history of Poland and through their narrative image present in historical writing, literature, and historical consciousness.

There were two issues in the socio-political situation in Poland after 1945: the Polishness of the Kresy of the Two Nations' Commonwealth which became part of the USSR and, after 1991, Lithuania, Belarus, and Ukraine; and the issue of the common Polish, Slavic, and also German history of Pomerania and Lower Silesia, and the presence in particular of German material culture in the lands settled by Poles expelled from their small homelands. The sense of injury mixed here with a peculiar "joy of revenge". The sense of strangeness in the new place did not give way easily under the pressure of knowledge about "returning to motherland" taught at schools and in official ceremonies. Throughout the PRL period, the discourse on the social consequences of the territorial changes of Poland after 1945 was, as particularly politically sensitive, was controlled by state institutions. It changed drastically after 1989, when preventive censorship was abolished, yet many other things also changed, as the generation which knew Poland only in its "Yaltan" borders came to the fore. Volhynia, Podole, and the Vilnius Region are terms known from historical texts, sometimes from parents' tales. Whereas Wrocław, Owl Mountains, and Kołobrzeg are remembered from school trips or holidays, or simply places where they live. This article will analyse the works of authors born in the People's Poland ( $P R L)$, for whom Recovered Territories are simply their homeland.

By the end of the 20th century, the socio-political, economic, and cultural conditions of the Polish society also changed drastically; this time, however, without shifting political borders (even though the very meaning of borders changed). As the extent of changes and systemic transformation in Poland and whole Central and Eastern Europe is not a subject to be exhausted in a single work, we shall focus on a single

1 Hanna Gerlich, “Obrazy świata minionego - oswajanie ziem zachodnich. Analiza jednego przypadku w świetle relacji autobiograficznych" [Images of the past world: Domestication of the western territories], Etnografia Polska, Vol. XXXVIII: 1994, is.1-2, p. 26-45. 
aspect of it: the changes in the historical consciousness and knowledge comprising the collective identity of Poles.

There was a dynamic change at the turn of the 21 st century in the substratum of historical consciousness, the repositories storing the knowledge necessary for individuals and social group to develop identities. In the 20th century, two discourses played a major role in shaping individual and collective consciousness: the discourse of memory of the family/closest social environment of an individual, dominant in the period of primary socialisation, and the discourse of official knowledge in common circulation, comprised of professional narrations of history, literature, and journalism, commissioned by the state and supplemented by an equally professional and somewhat "official" discourse of the opposition. Characteristically, the public discourse, both of the state and opposition) strongly affecting the historical consciousness of 20th-century Poles, was professional, which means regulation of the content of the message according to the traditional rules of the given discourse, enforced by a group of highly authoritative specialists. Whereas the non-dominant factor was the flow of information between the recipient of a message and its author. In effect, this meant that writers, for an instance, were more concerned with the opinions of literary critics, colleagues who were authorities in their milieu, and magazine editors, than readers. It was also largely the case of historians, publicists, and film directors.

At the turn of the 21st century, Polish culture and identity discourses, which were part of it, came under a "self-funding" pressure in the conditions of a free market of cultural goods, which led to a dynamic development of mass culture.

The specific trait of mass culture products is that it shows the mass audience images of the world which coincide with their reception of reality. A feedback loop forms between the images best fitting the expectations of the mass audience, which replicates certain ways of describing the world, plot themes, character patterns, and narrative schemas. ${ }^{2}$ In the products of Polish mass cultures of the early 21 st century, we shall pay attention to the repeating connections between the described phenomena and the meanings, symbolic categories, and axiological values accompanying them. Another issue to which we shall pay attention is the nature of the emotional feedback between the components of a description and its recipient. Since the products of mass culture evoke not only semantic associations but emotional reactions as well, they may serve as the empirical basis for the research into not only collective consciousness understood as collective knowledge of the world, but also mentality, or the unconscious, emotional reception of reality. By analysing the phenomena of

2 Cf. Antonina Kłoskowska, Kultura masowa. Krytyka i obrona [Mass culture: Criticism and apology], Warszawa, 2005, p. $97-105$ 
mass culture, and collective consciousness and mentality through them, we enable ourselves to reach the phenomena which form social identity, i.e., the unconscious categories based on which we intuitively "know", or rather "feel" who we are.

Historical topics are clearly visible in the Polish popular literature of the turn of the century. Even though they do not always take the "pure form" of historical novels or popular-historical works, they are often found in syncretic literary works combining the genres of historical, crime, and fantasy literature. Artifacts of mass culture are often similarly ill-defined, since it leaves their authors more freedom to use various themes and storytelling conventions enjoying the recognition and interest of recipients-consumers.

Similarly, the region of Lower Silesia and Wroclaw seems to be attractive to authors following this cultural trend due to its ill-defined nature and certain heterogeneous historical depth produced by millennia of rich, and thus regrettablly bloody, history.

We may visit the Piasts' Silesia of 1236-1241 thanks to the historical-picaresque trilogy by Tomasz Łysiak: Szalbierz [Con man] ${ }^{4}$, Bliznobrody [Scarbeard] ${ }^{5}$, and Psy Tartaru [Hounds of Tartarus] $]^{6}$. These are tumultuous times of wars for dominance in the Polish Kingdom divided into duchies-provinces; times when the Polish lands are visited by foreign merchants, knights and knightly orders, times of the impending Tartar onslaught. We follow the title character, the con-man named Jerusalem, a half-Tartar, who came to Poland to spy and prepare the imminent invasion but renounces his past when he discovers love to a woman and a child; knight Dragaila, bearing Kraplan coat-of-arms, a forerunner of the western "knight errant" idea, proud of his descent from St George, heroic deeds in defence of the faith, and his terrible sword named "Hoodripper"; his squire Karlito, a cynical humpback, who masks his sincere devotion to his master with repulsive look and terrible manners; Hannah, a girl endowed with prophetic talents, with whom Jerusalem will fall in love after a long struggle with himself and for whom he will abandon his people; and a mysterious boy with a strange tattoo on his chest, sought by strange armed monks in black masks.

Reading the novel, we find sudden plot twists but also the life of medieval Wrocław, turning into a multi-ethnic metropolis, where German merchants trade in overseas goods, thieves and beggars have their own holidays, Duchess Hedwig performs charitable acts, and an old Yotvingian plots to hand the city to the approaching Mongols.

\footnotetext{
3 Cf. John Storey, Inventing popular culture: from folklore to globalization, Oxford, Malden, 2003, p. 78-91.

4 Tomasz Łysiak, Szalbierz, Warszawa 2007.

5 Tomasz Łysiak, Bliznobrody, Warszawa 2008.

6 Tomasz Łysiak, Psy Tartaru, Warszawa 2010.
} 
The last book of the cycle bears a strong mark of Duke Henry the Pious, true to his name: an actual Christian ascetic as well as a Polish patriot who fought German margraves for the Lubusz forts and, above all, bravely defended his duchy against the mighty Mongol army. In the last pages of the book, the author refers to a novel hypothesis that the duke was not slain during the battle at "Dobre Pole" (lit. Good Field) near Legnica but rather was imprisoned and later beheaded in front of the Mongol commander's tent when he refused to bow. The story of his death is modelled after the death of Christ in the Gospel of John, infusing his character and the events with mysticism: the blood of a martyr was spilled on the Land and for the Land.

The events of the "Hussite" trilogy by Andrzej Sapkowski, composed of the novels Narrenturm ${ }^{8}$, Boży Wojownicy [God's warriors] ${ }^{9}$ and Lux Perpetua ${ }^{10}$, taking place 200 years later, are also permeated by a mystical atmosphere of historical fantasy. The story takes place mainly in Lower Silesia and the Czech lands. The Protagonist, Reinmar von Bielau, a medic and fledgling mage, is involved in religious wars, political intrigues, and the gnostic struggle of light, reason, and love with darknes, stupidity, fanaticism, and cruelty.

The Silesia of Sapkowski's trilogy is a trans-frontier territory, where magic mingles with material reality, Polishness and Slavic-ness with Germanity, faith with hypocrisy, cruelty with love. It is a crucible where new ideas are born, fuelled by old and very old matters. The Hussite struggles against German and Polish crusaders are observed by creatures of the magical and pagan past, living relics of the ancient times, powerless to prevent the coming of the new. The antiquity of Silesia is often emphasised: by the ubiquity of magic, a power owing its vitality to being deeply rooted in time and space, but also by fatigue and readiness for the change which will end the cruelty. There are Piast dukes in the novels: representatives of a dynasty tired of ruling, tainted with savagery, and doomed to perish not unlike the forest monsters, gnomes, and werebeast shape-shifters. We watch a rapidly changing world: the old dies and in its death throes the new is born. The world of pagan magic beings and the world of the Piasts are fading away, replaced by Germans and Czechs as well as reformed Christians, modern, disciplined, and ruthless in their devotion (both Hussites-protestants and Catholics), bringing with them the power of religion and technology: a new magic based on books, research, and experiment. They also bring along total war and ruthless fanaticism. The new world, however, proves no better than the old one, it simply

\footnotetext{
7 Cf. T. Łysiak, Psy Tartaru [Hounds of Tartarus], Warszawa 2010, p. 499-500.

8 Andrzej Sapkowski, Narrenturm, Warszawa 2002.

9 Andrzej Sapkowski, Boży Wojownicy, Warszawa 2004.

10 Andrzej Sapkowski, Lux Perpetua, Warszawa 2006.
} 
has greater destructive potential. Sapkowski describes a world stretched between many dimensions of reality: magical and real, Polish, German, and Czech, catholic, pagan, and Hussite (protestant), as well as historical and modern. The language of the trilogy is a daring blend of archaised style (with references to the classics of Polish historical novel, Sienkiewicz and Kraszewski) with the ultra-modern Polish of the youth. The protagonists discuss social, philosophical, and religious issues using remarkably current notions and categories intertwined with old-Polish words. The narration is similarly inconsistent: once modern, once archaised. Reading the novel, we get the impression of making fluent transitions between worlds, now in historical reality, then in modern times.

This suspension "between" the supernatural and the real dimensions of reality can also be found in Wrocław in the novel Gallery of city wonders (Pol. Poczet dziwów miejskich) by Krzysztof Piskorski." Its story runs parallel in the modern capital of Lower Silesia and in the "unnaturban" dimension of the city. Thus, we make acquaintance of vodyanoy, gnomes, gargoyles (from the cathedral), and basilisk Zhmf, hiding in the cellars. This whole magical host does not live as they fairy-tale ancestors did since they adapted to living in a non-magical world just as foxes and boars adapted to living on the outskirts of cities.

Rrax the Raven, endowed with magical properties, is the oldest living inhabitant of Wrockaw, owing it to his reason and the habit to keep away from the historical turmoil affecting the region (in both dimensions). During Bretislaus' Raid, he was "curing a cough" in the forest, and when in the 13th century "raucous" kobolds came to Wroctaw and started a war against the local strange folk, he hid in a tree hollow.

Piskorski's book is told in a humorous tone and filled with witty episodes involving a fruit winery employing dwarfs, due to the high sulfur content in their urine; Baba Yaga, defeated by a student of ethnology and Rrax the Raven, finds employment as a washroom attendant; Wroclaw is visited by time-travelling Soviet special services, etc.

Nonetheless the magical or mystical nature of the city may be emphasised in an entirely different style, which is the case of the Holy Wroctaw (Pol. Święty Wroctaw) by Łukasz Orbitowski. ${ }^{12}$ The image of the city is painted in shades of grey, the city is wanting, the people are wanting, not very bad (though there are many stupid and nasty ones) yet certainly not good: a corrupt lawyer, a drunkard dentist, workers, bums, several nut cases, jaded school kids. Only Michał and Małgosia, in love with each other, seem a bit likeable, if anyone. In these surroundings, at the end of a cold winter, the "Holy Wrocław" appears in one of the prefab concrete housing cooperatives: in one

\footnotetext{
11 Krzysztof Piskorski, Poczet dziwów miejskich, Lublin 2007.

12 Łukasz Orbitowski, Święty Wrocław, Kraków 2009.
} 
of the blocks, a black, warm surface emerges from beneath bathroom tiles, wallpapers, and linings. It is hard but somehow "innervated", neither dead nor alive; it starts attracting people who, entranced, free it from the concrete. The whole block begins to transform, absorbing its inhabitants and everyone who enters. A prophet emerges in the town, announcing the imminent end of the world. Only the "Holy Wrocław" and those who became its part and now remain suspended "between life and death" may withstand it. The location spreads, absorbing more and more people, yet it does not accept everyone. The corrupt lawyer does not become a part of the "Holy Wrocław" but is torn apart by its "inhabitants" instead. Whereas a young girl, Małgorzata, sinks in it when her spiteful friends, jealous of her boyfriend Michal, throw her in. Pilgrimages of praying worshippers start coming from the whole Poland and other countries, but their path is blocked by a police cordon. The missing girl's father and fiancé also try to break through it. When they succeed and reach the "Holy Wroclaw", they find whole generations of undead there: present-day inhabitants of Wrocław, German and Soviet soldiers, Piast dukes... Soon, though, the prophecies shall be fulfilled, since the expected end is coming.

It is characteristic of Orbitowski's prose to describe unusual events like the most mundane things. The "Holy Wroclaw" appears in a specific block at a specific settlement, we learn which shops and food establishments are around, how much is pizza, which colour the staircases are painted, what tests there are in the final highschool grade, and which film the characters are watching on the computer screen. The apocalypse takes place at a specific place and time, affecting specific people. The palpable, concrete nature of the world in which we live will not protect it...

Wroctaw also appears as a place of a global disaster in a number of novel by Robert Szmidt: especially in the Apocalypse of Mr Jan (Pol. Apokalipsa wedtug Pana Jana $)^{13}$, told in the mood of fantasy and sensation, where the fates of Poland and Europe are intertwined with the history of the Polish borderlands, both old and new. In the face of an imminent global conflict, the Polish government decides to "liberate" Lviv and old Polish provinces from the Ukrainian "occupation". Ukraine responds with a nuclear strike on the Polish territory, which wipes the majority of the population from the face of the earth, turning the rest into bloodthirsty mutants. The future of the continent will be decided by the people who survived in old German shelters under the mountain of Ślęża, while Wrocław, the city held by its president - "Mr Jan" - with an iron hand has the opportunity to become the chief metropolis and quasi-capital of the devastated Europe.

13 Robert Szmidt, Apokalipsa wedtug Pana Jana, Katowice 2003. 
The end of the world (very concrete and historical in this case) and its coming, which we follow along the events occurring in the city of Breslau, is the canvas of a whole cycle of crime novels by Marek Krajewski (the cycle consists of: Śmierć $w$ Breslau [Death in Breslau ] ${ }^{14}$, Koniec świata w Breslau [End of the world in Breslau] $]^{15}$, Widma w mieście Breslau [Phantoms in Breslau] ${ }^{16}$, Festung Breslau ${ }^{17}$, Dżuma w Breslau [Plague in Breslau $]^{18}$, Gtowa Minotaura [Minotaur's Head ${ }^{19}$ ].

Together with police officer Eberhard Mock, the protagonist of the cycle, we witness the long decay process of the city and the world. As observers, we are exposed to virtually all kinds of depravity, corruption, and crime. We watch prostitution, all kinds of sexual deviations, drunkenness, incest, brawls, embezzlement, rapes, and finally inflicting death in various forms and colours. Nevertheless, Wrocław (Breslau) described in Krajewski's colourful style is not a travesty. The life carries on as normal, people work, raise children, eat eels topped with dill sauce and fried onions, eat Miksch's Baumkuchen, and drink Haase's beer snacking on delicious Friedrichhof crackers. Reading the books from the cycle we can often observe typical city life, yet there is putrid flesh under the pink skin of the city. The rot first affects the elites, aristocracy, high officials, physicians, lawyers, and police officers. When we get to know them better, they turn out to be mean, false, cowardly, and greedy, and the most likeable of them drink like a fish. The seemingly innocent are no better than criminals, criminals are mad and unaware of what they do, and only those who are too stupid, primitive, and cruel to lie do not. Quite often crimes are irrational, not simply due to wrath, hatred, or the desire for wealth: they are committed to prove an occult thesis, hasten the end of the world, or gain admission to a dark sect.

Wrocław resembles Rome, and lack only the sole righteous man to be Sodom. This man is not Mock: more Petronius than Lot, an aesthete and lover of antique literature but also a drunkard and lecher. Although he constantly uses blackmail in his work and often takes pleasure from it, he has not yet lost his humanity or a certain professional honesty, which makes him turn a blind eye to small transgressions (of his own and others) but pursue and punish cruel crimes.

The times are getting worse and worse even for Eberhard Mock, skilfully minding his business and career. When criminals from SA and SS gain power, even worse than the criminals he was catching so far, he does not choose between good and evil

\footnotetext{
14 Marek Krajewski, Śmierć w Breslau, Wrocław 1999.

15 Marek Krajewski, Koniec świata w Breslau, Warszawa 2003.

16 Marek Krajewski, Widma w mieście Breslau,Warszawa 2005.

17 Marek Krajewski, Festung Breslau, Warszawa 2006.

18 Marek Krajewski, Dżuma w Breslau, Warszawa 2007.

19 Marek Krajewski, Głowa Minotaura, Warszawa 2009.
} 
any more but between a lesser and a greater evil. Still, however, as one of the few in this rotting and declining works he wants justice, even if he does not always follow it himself. In the dying and burning Breslau in the last weeks of the siege of the fortresscity, amidst the omnipresent violence, suffering, and debauchery of those who still can afford to be debauched, Mock is conducting his last investigation, which makes him fully aware of the corruption of the world turning to non-existence.

Krajewski's books make us (us Poles, us "conquerors" and inhabitants of Wrocław) able to feel like barbarians, yet justified barbarians, in a way. We did not destroy the world which was here: it turned on itself, we just claimed the ruins...

The issue of justification of the capture/liberation of Wroclaw is clearly pronounced in the book Breslau forever by Andrzej Ziemiański. Within, we may find an optimistic philosophy of the history of Poland, the exposition of which was perversely entrusted to a German, Richard Kruger, a veteran of fights against the locals during the Silesian Uprisings. At the beginning of the book, whose plot starts on 1 September 1939 in the German city of Breslau, we meet him together with his friend (and character important later in the story) Albert Grunewald..$^{20}$ The city is full of enthusiasm since the war against Poland has just begun and there are first positive news from the frontlines. The Black Reichswehr veteran, recalling the struggle for St Anne Mountain where he lost his hand, does not join in the revelry. He expresses the view that a war with Poland will lead to a fatal succession of misfortunes as the Poles will "make a pact with the devil" and "pay all they have got" but they will keep retaliating until they take Breslau (Kruger is worried which barbarian name it will be called) and hang their flag in the burnt Berlin. The author plays with the character of Kruger who in 1939 learns the phrase "I didn't belong to NSDAP" in Polish and, reminded not to be a defeatist in the city where the Fuehrer himself is an honorary citizen, he "prophesises" tat a pope, and a Polish pope, will be its honorary citizen too. He is also afraid that Poles will interrogate him in his own office in the police building, which indeed takes place later in the novel. The interrogators are militiamen, Miszczuk and Wasiak, Polish peasants from Podole who, according to the narrator, payed the devil with all they had: they lost families, possessions, their homeland in the Kresy; they fought in the Soviet army, stormed the Festung Breslau, and then reported to work in the People's Militia newly formed in Wroclaw. Even though they are simple men, they clearly realise that "It took allying with the devil to take Breslau from them."

Wroclaw is not just the devil's collateral redeemed by the Poles with blood, martyrdom, renouncing centuries of tradition, and loss of the beloved lands in the

20 Andrzej Ziemiański, Breslau forever, Lublin 2008, p. 3-6.

21 A. Ziemiański, Breslau forever, Lublin 2008, p. 10. 
East: it is also a place of a remarkable mental and civilisational relay run. The plot of Breslau forever focuses on an investigation into mysterious murders, conducted first by a Kripo officer, then the militiamen mentioned above, then by our contemporary, a police officer from Wrocław. It is thus a palimpsest location of unique historical depth where the fortunes of peoples, nations, and cultures afflicted by history and fate are intertwined.

Wroclaw is the city where Eberhard Mock tracked depraved murderers. It is also the city where Edward Popielski, a policeman from Lvov, Home Army soldier, private detective and killer lived and died. He is the protagonist of a series of crime novels by Marek Krajewski, overlapping with the Eberhard Mock cycle (the first novel, Głowa Minotaura, published in 2009, belongs to both series. Its sequels are Erynie [Erinyes] ${ }^{22}$, Liczby Charona [Charon's numbers] ${ }^{23}$, Rzeki Hadesu [Rivers of Hades] $]^{24}, W$ otchtani mroku [In the abyss of dark $]^{25}$, Wtadca liczb [Lord of numbers] ${ }^{26}$ ). Lvov and Wrocław, Mock and Popielski. The history of the friendship of two police officers by trade, classical philologists by education, revellers and rakes by passion is linked to the history of two cities: cities connected by the crimes of a deviant nicknamed "Minotaur", cities bound by fate's decrees, which expelled the people from Lvov and made them inhabitants of Wroctaw in the place of the exiled dwellers of Breslau.

Wrocław, a city with rich but foreign and hostile history is a theme spurring the imaginations of the authors and readers of their books. The criminal past of Wroctaw is the basis of the plot of Krajewski's novels. Whereas Andrzej Ziemiański, in his story "Scent of glass" from the collection bearing the same title uses the theme of the past in an equally dark secret as the cases solved by Eberhard Mock. For, under the city of Wrocław, there is another city, a ghost: Festung Breslau, a maze of bunkers hiding the Nazi wunderwaffe, a weapon meant to turn the tide of war, prepared and defended until the last, defended longer than Berlin...

In Ziemiański's story "Legend" 28 , found in the same Scent of glass collection, the theme of palimpsest city is expanded. The present-day Wroclaw hides not only the secrets of pre-war Breslau, where the Nazis built mysterious bunkers, and which they defended until the last bullet. In the living and changing "city tissue" one can find cornified remnants of its previous stages as well as symbols embedded there

\footnotetext{
22 Marek Krajewski, Erynie, Kraków 2010.

23 Marek Krajewski, Liczby Charona, Kraków 2011.

24 Marek Krajewski, Rzeki Hadesu, Kraków 2012.

25 Marek Krajewski, W otchtani mroku, Kraków 2013.

26 Marek Krajewski, Wtadca liczb, Kraków 2014.

27 A. Ziemiański, Zapach szkła, Lublin 2004, p. 5-66.

28 A. Ziemiański, Zapach szkła, Lublin 2004, p. 104-173.
} 
by subsequent generations of builders and architects: secret passages and tunnels, stairs leading from nowhere to nowhere, stones bearing weathered words. Wrocław is a palimpsest, the depth of which does not end in two layers because every time we uncover one, it turns out it hides another one, and yet another one. Wrocław, the actual Wrocław is transformed in Ziemiański's story into a dreamlike box of a city, in which another is hidden, then one more. The passages between them are secret, not available to everyone, and, like in the "Holy Wrocław" by Orbitowski, the passage has its price. The protagonists of Ziemiański's stories "Legend" and "Heisenberg bomb" pass between the city's dimensions by entering a dream-trance state. The city's dimensions are also parallel realities which, while different, are not fully independent: what happens in one dimension is compensated for in the other. In "Heisenberg Bomb", the German Breslau still exists and Poland, allied with the Nazi Germany, wages war against the USA. In "Legend", Poland led by a Chinese female president enjoys a period of calm and prosperity compensated with wars, plagues, and partitions in "our" reality. In both stories Wroclaw is the key, the city-gate between dimensions. Ziemiański underlines the uniqueness of Wrocław even more clearly in his story "Autobahn nach Poznań" ${ }^{30}$ written in the "cyber-punk" sub-genre of science-fiction. The story is a reference to Szmidt's novel Apocalypse of Mr Jan. The story takes place in an already post-apocalyptic world, where people live in bunkers and the surface is ruled over by mutant hordes. The exception is Wrocław, where people can live normally protected by the dome (built by Mr Jan - a reference to Szmidt's novel) shielding them from radiation and massive walls separating them from the mutants. The city has wide economic connections, the most important of which is Poznań, now a strategic port on the Atlantic coast), connection with which is maintained owing to a 4-lane motorway protected by armed to the teeth foreign mercenaries (speaking a colourful Polish-German-Ukrainian dialect) and trained mutated animals. The plot is based on an intrigue of the American government to transport a military unit in time and regain the lost hegemony, which pal is thwarted by a general from Wroctaw.

Wrocław has been and still is changing, each historical turmoil carves deep scars in its shape. Its inhabitants also change: they die, are killed, escape, are carried away and brought in. The city is in constant motion - even its name changes - if there is something which manages to remain unchanged in such historical paroxysms, it must be unusual, even magical. In Piskorski's Gallery of city wonders this role is played by Rrax the Raven, the oldest citizen of the "unnaturban" Wrocław. In Ziemiański’s

29 A. Ziemiański, Zapach szkła, Lublin 2004, p. 78-102.

30 A. Ziemiański, Zapach szkła, Lublin 2004, p. 266-310. 
"Wrocław raspberry plantations" ${ }^{31}$ we meet a man who has been living for centuries, magically bound to the Ślęża. When every few decades he manages to get away from it, an accident happens, after which he gains new identity and memory. The Ślęża is shown here as a temporal axis mundi, the axle of the world around which history and events are turning, from stone age to the futuristic "vanilla plantations" in Wroclaw.

The idea of a historical continuum with Wrocław and Lower Silesia at its centre can be found in the books by Iga Karst, who continued the cycle about the historian and detective "Mr Automobile" (Pol. Pan Samochodzik), created by Zbigniew Nienacki. In the novels Pan Samochodzik i perty księżnej Daisy [Mr Automobile and Duchess Daisy's pearls] $]^{32}$ and Pan Samochodzik i podziemia Wroctawia [Mr Automobile and the Wroclaw underground $]^{33}$, we travel across Lower Silesia with Mr Tomasz and his relatives Zosia and Jacek seeking the stolen works of art and tracking the wrongdoers responsible for art theft and other crimes. The troubled history of the visited towns and villages, castles, palaces, as well as vast dungeons and the bunkers of Wrocław play a significant role in the books but, contrary to Krajewski and Ziemiański's prose, they do not create the atmosphere of foreignness. These are simply places of rich history, which left traces in the form of curious architecture and puzzles, fascinating for every historian and antiquarian. The foreignness is not there, the wealth is. The concept of continuum predominates the metaphor of boundary-Styx, so clearly drawn in Ziemiański and Orbitowski. Historical turmoil is part of the normal world, not the result of a dark fate. Time heals the wounds dealt by history, the memory accrued around places and human works remains.

The authors of the texts presented above were born in the PRL period, often after 1970, therefore they belonged to the generation which did not know Poland other than in its post- 1945 borders. It is their motherland. This is a generation, however, which had to confront various views of history and images of Poland: the official one and the one they knew from the stories of their parents and older relatives. The idea of the Lost Poland - Lvov and the Vilnius Region - is present here, in particular in the prose of Ziemiański and Krajewski. The presented works belong to broadly defined popular culture: crime stories, adventure, science-fiction, fantasy, humorous, and horror novels. Still, there is a certain historiosophical view, and they may be read as

\footnotetext{
31 A. Ziemiański, Zapach szkła, Lublin 2004, p. 174-216.

32 Iga Karst, Pan Samochodzik i perty księżnej Daisy, Olsztyn 2005.

33 Iga Karst, Pan Samochodzik i podziemia Wroctawia, Olsztyn 2007.
} 
an attempt to resolve the paradox afflicting the generation of people living with the feeling that they lost the land of their ancestors, and the sense of involuntary injustice they perpetrated taking over someone else's homes and lands. This paradox was created by the official historical policy of PRL, which tried to ignore the significance of the eastern territories, even though it was unable to silence many facts attesting to the contrary or remove the image of the "Kresy", made permanent by the great Polish literature, from the historical consciousness of Poles. It was paradoxical that, on the one hand, the traditional interpretation of patriotism was upheld, an important part of which was the commandment "never to abandon the land of our folk", and, on the other, a concept of historical justice was created and realised by abandoning the land of fathers and moving to the territories which were not politically Polish for centuries.

Authors born in PRL took advantage of the freedom granted by the seemingly "trivial" genres in the popular culture area to create an interesting and coherent view of history, which cancels the above paradox. By using the notions of "frontier", "continuum", and "palimpsest", this view of history moves the understanding of history from the concrete and historical to the symbolic and metaphorical level, taking care to prompt a quick, emotional reaction in this dimension with the means of literary expression. In the essence, it is not a new practice: it was previously employed by the great Romantic literature, by Sienkiewicz, who wrote "to lift hearts" in the area of the 19th-century pop-culture. Let us illustrate this literary and historiosophical practice with the story "Polish house" (Pol. Polski dom) by Ziemiański, from the collection Tesla's trap. ${ }^{3}$

In the story we meet a modern Polish family, accidentally stuck in the rain, on a road, without any means of transport allowing them to return to the city. Out of nowhere, there comes a well-dressed man, who offers them hospitality at his home, which turns out to be an elegant palace. The protagonists are received with unusual hospitality and elegance. The landlord, Count Bartowski, calls a physician to take care of the rain-soaked children, the dinner is served by the household staff, and even a parish priest joins the company to play cards. The eeriness of the scene is emphasised by such anachronistic details as long-unused medicines administered to the children who got cold by the physician, the fact that he knows nothing about antibiotics, and the statement which was the landlord's mantra that "his spouse was safe, on her way to England, protected by the coachman." In the morning, after breakfast, the mysterious count gives the protagonist a medallion with the words "Homeland - to its defender" and tells his servants to drive the guests to the railway station. From the windows of the train, the characters see the place where they spent such a pleasant night, which is charred ruins now. Another pas-

34 Cf. A. Ziemiański, Pułapka Tesli, Lublin 2013, p. 5-21. 
senger tells them a story about the people who lived in the mansion which stood there, murdered short after the war by unknown bandits. Only the countess survived of all the family, who managed to escape to England, saved by the coachman.

In the last scene, the protagonist takes out of his pocket the medallion, which not so lont ago was like new and is now old and stained with rust.

In this story, Ziemiański creates a view of the historical community on which patriotism is founded: it is a community, a continuum of the living and the dead, transcending the borders of reality and the real world; thanks to which every place and event in which we take part may be of a special importance to us and build our affiliation with the historical community of nation.

\section{TRANSLATION: Andrzej PIETKIEWICZ}

\section{BIBLIOGRAPHY:}

Gerlich Hanna, Obrazy świata minionego - oswajanie ziem zachodnich. Analiza jednego przypadku wświetle relacji autobiograficznych, Etnografia Polska, T. XXXVIII(1994)/1-2

Kłoskowska Antonina, Kultura masowa. Krytyka i obrona, Warszawa, 2005

Storey John, Inventing popular culture: from folklore to globalization, Oxford, Malden, 2003

Łysiak Tomasz, Szalbierz, Warszawa 2007

Eysiak Tomasz, Bliznobrody, Warszawa 2008

Łysiak Tomasz, Psy Tartaru, Warszawa 2010

Sapkowski Andrzej, Narrenturm, Warszawa 2002

Sapkowski Andrzej, Boży Wojownicy, Warszawa 2004

Sapkowski Andrzej, Lux Perpetua, Warszawa 2006

Piskorski Krzysztof, Poczet dziwów miejskich, Lublin 2007

Orbitowski Łukasz, Święty Wrocław, Kraków 2009

Szmidt Robert, Apokalipsa wedtug Pana Jana, Katowice 2003

Krajewski Marek, Śmierć w Breslau, Wrocław 1999

Krajewski Marek, Koniec świata w Breslau, Warszawa 2003

Krajewski Marek, Widma w mieście Breslau,Warszawa 2005

Krajewski Marek, Festung Breslau, Warszawa 2006.

Krajewski Marek, Dżuma w Breslau, Warszawa 2007.

Krajewski Marek, Gtowa Minotaura, Warszawa 2009.

Ziemiański Andrzej, Breslau forever, Lublin 2008

Ziemiański Andrzej, Zapach szkła, Lublin 2004

Ziemiański Andrzej, Putapka Tesli, Lublin 2013,

Krajewski Marek, Erynie, Kraków 2010

Krajewski Marek, Liczby Charona, Kraków 2011.

Krajewski Marek, Rzeki Hadesu, Kraków 2012.

Krajewski Marek, W otchłani mroku, Kraków 2013.

Krajewski Marek, Wtadca liczb, Kraków 2014.

Karst Iga, Pan Samochodzik i perly księżnej Daisy, Olsztyn 2005

Karst Iga, Pan Samochodzik i podziemia Wroctawia, Olsztyn 2007 